\title{
GERMINATION AND SEEDLING VIGOR RESPONSE OF WHEAT SEED TREATMENT METHODS TO SALINITY STRESS CONDITIONS \\ Mersal, I. F. ${ }^{1}$; S. E. Seadh ${ }^{2}$ and M. I. El-Abady ${ }^{1}$ \\ 'Seed Technology Research Department, Field Crops Research Institute, Agricultural Research Center, Giza, Egypt. \\ ${ }^{2}$ Agronomy Department, Faculty of Agriculture, Mansoura University, Egypt.
}

\begin{abstract}
Development of field crops tolerant to environmental stresses is considered a promising approach, which may contribute to increase its productivity under stress conditions. But, use of some seed treatment methods may be help to improve plant tolerance of salinity. Therefore, the objective of this study was to evaluate some seed treatment methods to alleviate the harmful effect of salinity on seed germination and seedling vigor of wheat (Triticum aestivum L.). Laboratory experiment, followed by pot experiment was conducted in 2013 year at laboratory natural conditions of Seed Technology Research Unit in Mansoura, Dakahlia Governorate, Field Crops Research Institute, Agricultural Research Center, Egypt. Seeds of wheat (cv. Miser 1) were treated with humic acid (in the form of Actosol) at the recommended concentration (5 $\mathrm{ml}^{-1}$ water) for 12 hour by different methods (soaking, priming and dressing). Germination and seedling vigor under control $\left(4 \mathrm{dsm}^{-1}\right)$ and saline $\left(6,8,10,12 \mathrm{dsm}^{-1}\right)$ conditions were studied to determine the usefulness of those methods in increasing relative salt-tolerance. Seedlings of treated seed of pot experiment sprayed with humic acid after 15 days from sowing.

The results showed that the best values of germination percentage, mean germination time, shoot length, root length and seedling dry weight were recorded when wheat seeds soaked in humic acid, followed by priming in humic acid solution. While, dressing seeds with humic acid method was the inferior one. Combination of soaking seeds and foliar application of seedlings with humic acid was more effective on seedling vigor as compared to soaking or priming seeds alone. The pre-sowing seed treatment which is an easy and low risk technique may be used as an alternative approach to alleviate agricultural salinity stress.
\end{abstract}

\section{INTRODUCTION}

The factors that decrease germination percentage and inhabit plant growth are defined as stresses. High or low temperature, drought, excess irrigation, $\mathrm{pH}$, heavy metals and salinity are common sources of stress. These stresses exceed the optimum tolerance of a plant and effect on the developmental structural, physiological and biochemical processes. Many pre-sowing seed treatment methods such as soaking, priming and dressing play a vital role in improving seed viability particularly, under adverse conditions. The varied between these methods in technique despite they use occasionally the same substance render them fluctuated in facing the detrimental effect of stress (Matsushima and Sakagami, 2013). Some of these methods may be suitable for one stress, but not success for others and another method are not feasible, is inconsistent or entirely unsuitable. 
Soil salinity among these environmental stresses causes economic problems. Every year more and more land becomes non-productive owing to salt accumulation. It inhibits crop growth by reduced hormone delivery from root to leaves (Sakr and El-Metwally, 2009). Most crop species are quite susceptible to salt injury at germination and stand establishment stages ( $\mathrm{He}$ et al., 2002).The effects of salinity on wheat seedling stage range from, reduction in germination percentage, shoot and root length and dry weight to the up-take of nutrient ions (Afzal et al., 2006). Seed germination and early seedling growth are the most sensitive stages to salinity stress (Muhammad and Hussain, 2010). Seedling growth characters significantly varied under different levels of salt (Mirzaei et al., 2012; Muhammad and Hussain, 2012 and Hussain et al., 2013). Germination rates decrease with an increase in $\mathrm{NaCl}$ concentration (Akbarimoghaddam et al., 2011). Increasing $\mathrm{NaCl}$ concentrations adversely affected shoot and root length of seedling and its dry weight in each cultivar by varying $\mathrm{NaCl}$ concentrations (Eskandari and Kazemi, 2011). This is adversely affecting growth and development of crop plants which lead to low agricultural production (Garg and Gupta, 1997).

In Egypt, salinity became a critical problem, particularly in the Delta Region. It is expected to increase due to expanded irrigation. Besides, the inherent salt tolerance capacities of some existing varieties different strategies are being employed to help plant growth under saline conditions among them application of some substances (Datta et al., 1998).

Pre-sowing seed treatment is an easy, low cost and risk technique and recently used to overcome agricultural salinity problems. Thus, the detrimental effects of high salts on the early growth of wheat seedlings may be reduced to some extent by treating seeds with the proper concentration of a suitable hormone (Darra et al., 1973). Humic substances have also a similar effect of hormones. Whereas, it is not clear whether it depends on their chemical structure or the molecular mass (Nardi et al., 2002). Using humic acid at various developmental stages stimulates rooting (Cooper et al., 1998), as well as the growth of above ground parts (Ayuso et al., 1996). Presowing seeds with optimal concentration of some natural and safety substances has been shown to be beneficial to growth and yield of some crop species growth under saline conditions by increasing nutrient reserves through stimulated physiological activities and root proliferation (Singh and Dara, 1971).

Research conducted using Humic substances has proved increase in seed germination, seedling vigor, yield and quality of several varieties of agricultural seeds (Malik and Azam, 1985; David, et al., 1994; Lulakis and Petsas, 1995; Ayuso et al., 1996; Dursun, et al., 1999; Canellas et al., 2002; Killi, 2004; Patil, 2011 and Szczepanek and Wilczewski, 2011). Germination percentages, shoot and root length and its dry weight and root /shoot ratio were significantly increased with soaking in potassium humate solution particularly at the rate of $100 \mathrm{~mL}^{-1}$ for 24 hours (Ali and Elbordiny, 2009). Humic acid has a positive effect on germination and early seedling growth of barley seeds. The greatest seedling growth parameters were observed in seeds primed at concentration of $750 \mathrm{mg} \mathrm{l}^{-1}$ for 12 hours (Asgharipour and Rafiei, 2011). The immersion of seeds in a sodium humate solution was 
reported to increase germination, water absorption, and respiration (David et al., 1994), the length of roots and shoots (Malik and Azam, 1985) and the fresh and dry mass of roots and shoots (Lulakis and Petsas, 1995). Root length and shoot length of crop plants are positively affected by humic acid application (Asenjo et al., 2000 and Khan and Mir, 2002). The humic acid applied seedlings had at least $1.65 \mathrm{~cm}$ longer shoots than control (Turkmen el al., 2005).Tejada and Gonzalez (2003) showed that the application of humic acids to plants increased water absorption and germination rate. Killi (2004) indicated that the effect of soaking in potassium humate solution caused significant increases in germination characteristics. Habashy and Aly (2005) indicated that the nitrogen, phosphorus and potassium in wheat grains have been significantly increased due to application at $50 \mathrm{ppm}$ humic acid.

Humic substances are excellent foliar fertilizer carrier and activators. Application of potassium humate in combination with major nutrients, as foliar sprays can improve the growth of plant. Combination of soaking seeds with potassium humate and foliar application were more effective on $\mathrm{N}, \mathrm{P}$ and $\mathrm{K}$ uptake by wheat plant and yield quality as compared to soaking seeds alone, especially when application of K-humate is enriched with N, P and K (Ali and Elbordiny, 2009). Humic acid application in all the three methods (soil applied, seed priming and foliar spray) significantly enhances plant growth of mungbean (Waqas et al., 2014).

The objective of this study was to evaluate some seed treatment methods in order to alleviate the harmful effect of salinity on seed germination and seedling vigor of wheat.

\section{MATERIALS AND METHODS}

All experiments reported in this study were carried out in 2013 season at laboratory natural conditions of Seed Technology Research Unit in Mansoura, Dakahlia Governorate, Field Crops Research Institute, Agricultural Research Center, Egypt. The objective of this study was to evaluate some seed treatment methods to alleviate the harmful effect of salinity on seed germination and seedling vigor of wheat. Seeds of wheat (Triticum aestivum L.) Cv. Miser 1 which harvested in 2013 season were obtained from Wheat Research Department, Field Crops Research Institute, Agricultural Research Center, Egypt.

Before the start of experiment, seeds were surface sterilized in $3 \%$ sodium hypochlorite solution for $3 \mathrm{~min}$, then rinsed with sterilized water and air-dried. (ISTA, 1985) and surface dried by placing them between paper towels for $30 \mathrm{~min}$. at room temperature.

\section{I- Laboratory experiment}

Preparation of $\mathrm{NaCl}$ solutions:

The solutions were prepared based on methods of Rhoades et al. (1992) with electrical conductivity (EC) of 4.0 (as control), 6.0, 8.0, 10.0 and $12.0 \mathrm{ds} \mathrm{m}^{-1}$.

\section{Seed treatment methods:}

The carrier of humic acid was Actosol (20\% Humic acid, $6 \% \mathrm{~K})$. The study employed six seed treatments: 
1) Soaking in humic acid : Seeds were sub- merged in humic acid at $30^{\circ} \mathrm{C}$ for $12 \mathrm{~h}$ just before sowing;

2) Priming in humic acid: Seeds were submerged in humic acid at $30^{\circ} \mathrm{C}$ for $12 \mathrm{~h}$, dried back to attain initial seed weight before sub- merging in humic acid at $25^{\circ} \mathrm{C}$;

3) Soaking in distilled water: Seeds were sub- merged in distilled water at $30^{\circ} \mathrm{C}$ for $12 \mathrm{~h}$ just before sowing;

4) Priming in distilled water: Seeds were submerged in distilled water at $30^{\circ} \mathrm{C}$ for $12 \mathrm{~h}$, dried back to attain initial seed weight before sub- merging in distilled water at $25^{\circ} \mathrm{C}$;

5) Dressing with humic acid : Seeds were shaken with humic acid for 20 minutes and 6) Control seeds were not submerged or dried .

Seed germination and seedling vigor trails:

Germination measurements of the wheat seeds was estimated in accordance to the Rules of ISTA (1985). Four replicates of 25 seeds each were germinated in $12 \mathrm{~cm}$ diameter petri dishes at $25^{\circ} \mathrm{C}$ in growth chamber. Before this, $5 \mathrm{ml}$ of different saline solutions $\left(4,6,8,10\right.$ and $\left.12 \mathrm{ds} \mathrm{m}^{-1} \mathrm{NaCl}\right)$ were added to the Petri dishes that were arranged in a randomized complete block design under factorial arrangement to impose salinity stress, while the EC $4 \mathrm{ds} \mathrm{m}^{-1}$ was applied as control. A seed was scored germinated when radical lengths reached $2-3 \mathrm{~mm}$. Counts of germinating seeds were made every day, starting on the first day of sowing, and terminated when maximum germination was achieved. During this, mean germination time (MGT) was calculated according to the equation of Ellis and Roberts (1981):

$$
\text { MGT }=\frac{\sum D \mathbf{n}}{\sum \mathbf{n}}
$$

Where $\mathrm{n}$ is the number of seeds germinated on day $\mathrm{D}$, and $\mathrm{D}$ is the number of days counted from the beginning of germination.

Shoot length and root length of seedling (10 representatives) were measured and after that seedling dried in a forced air oven at $110^{\circ} \mathrm{C}$ for 17 hours (Agrawal, 1986) to obtain seedling dry weight and expressed as milligrams.

\section{II- Pot Experiment}

In order to study the effect of foliar spraying with humic acid (Acetol: $20 \%$ Humic acid, $6 \%$ k) on seedling vigor, a pot experiment was conducted after treated wheat seed with different methods, 100 seeds from each treatment were immediately planted into pots containing $2 \mathrm{~kg}$ soil and sown at $0.5 \mathrm{~cm}$ apart. The soil was taken at $0-20 \mathrm{~cm}$ depth from fields of Sandoob Village near Mansoura City. Chemical and physical analyses were conducted according to Piper (1950). The soil texture was silt clay (8.99\% sand, 39.96\% silt, $44.64 \%$ clay). $\mathrm{pH}: 8.1$, EC ds $\mathrm{m}^{-1}$ (1:5):4. Available N, P, K: 33, 14, 119 ppm, respectively. The pot dimension was of $25 \mathrm{~cm}$ diameter and $30 \mathrm{~cm}$ depth. Treatments were replicated three times for the factorial experiment in Randomized Complete Block Design, average temperature was $\left(20 / 17{ }^{\circ} \mathrm{C}\right.$ day/night; under $11 \mathrm{~h}$ day length). Soil salinity completed by different salt solution to reach field capacity of $4.0,8.0$ and $12.0 \mathrm{ds} \mathrm{m}^{-1}$ from $\mathrm{NaCl}$. Field capacity of the soil was assessed using a method described by Kawaguchi (1974). A foliar spray application with humic acid was applied after 15 days 
from sowing with the same rate used in laboratory experiment $\left(5 \mathrm{~mL}^{-1}\right)$. Emergence of the plamule from the soil was regarded as successful germination. The emergence percentage seeds emerging to the surface were calculated daily and recorded. Mean emergence time (MET) was calculated according to the equation of Ellis and Roberts (1981). Final length of shoot and root was measured of 10 seedlings representative after 40 days separated carefully, the seedling biomass was gently washed to remove the soil and shoot length was measured $(\mathrm{cm})$. Seedling then dried at $105^{\circ} \mathrm{C}$ for 24 hours and weighed to express seedling dry weight as milligrams.

Data was statistically analyzed according to the technique of the analysis of variance (ANOVA) for the factorial experiment in Randomized Complete Block Design according to Gomez and Gomez (1984). The means of treatments were compared using the Least Significant Differences (LSD) method as described by Snedecor and Cochran (1980).

\section{RESULTS AND DISCUSSION}

\section{I- Laboratory experiment}

The results obtained from Table 1, indicated that germination percentages were influenced by salinity levels, as salt concentration increased germination percentage decreased. However, the decrease was greater in $12 \mathrm{dsm}^{-1}$ than the other treatments was $92.3 \%$. The germination\% gradually increased from 94.2 passing by 95.5 and 96.6 until reach to $97.8 \%$ with decrease in salt concentration from $10,8,6$ and $4 \mathrm{ds} \mathrm{m}^{-1}$, respectively.

Seed treatments in humic acid or distilled water enhanced germination\% than untreated seed (control). Among seed treatment methods, soaking in humic acid proved to be the best method whereas, produced the highest germination percentage followed by priming in humic acid method (98.6 and $97.6 \%$, respectively). Conversely, the lowest germination percentage was produced with dry seed (control) and followed by dressing method (91.5 and $94.1 \%)$.

The interaction between seed treatment methods and salinity levels on germination percentage was significant. When seed germinated in the lower salinity level $\left(4 \mathrm{dsm}^{-1}\right)$, the germination was 99.6 and $99.3 \%$ with soaking in humic acid and priming in humic acid, respectively. Increased salinity level up to $12 \mathrm{dsm}^{-1}$ (the highest level), produced germination $85 \%$ with untreated seed but, treated seed in humic acid raised the germination up to 97.3 and $95.6 \%$. The dressing method was the inferior method of germination (91\%) but, treated seed with humic acid by different methods (soaking, priming or dressing) enhanced germination percentage to considerable degree even at $12 \mathrm{dsm}^{-1}$ and decreased the decline in germination percentage. However, soaking seed in humic acid, closely followed by priming method, for $12 \mathrm{~h}$ produced the highest germination percentages as compared with the other methods. Humic acid soaking seemed to be more effective than in the absence of salts. With further increase in salt concentration, however, humic acid soaking proved to be less effective. Although the germination percentages decreased with salinity levels particularly in high salinity levels, the values tended to be above the wheat acceptance level (85\%) for certified 
wheat seed. Noticeably, soaking or priming in distilled water preceded dressing method despite using humic acid. These results are in line with Maas and Nieman (2000) they found that higher concentration of salt reduces the water potential in the medium which hinders water absorption by germinating seeds and thus reduces germination. Meanwhile, Smith and Comb (1991) reported that salinity $(\mathrm{NaCl})$ may also affect germination by facilitating the intake of toxic ions which may change certain enzymatic or hormonal activities of the seed. Canellas, et al., (2002) also reported that such positive effects of humic acid on plant growth is a concentrationdependence phenomenon and may be due to hormone-like activity of humic acid on cellular respiration, photosynthesis, membrane permeability of root cells, protein synthesis and various enzymatic reactions.

Table 1: Germination percentage as affected by seed treatments and salinity levels as well as their interaction under laboratory conditions.

\begin{tabular}{|c|c|c|c|c|c|c|}
\hline \multirow[b]{2}{*}{ Seed treatments } & \multicolumn{5}{|c|}{ Salinity levels } & \multirow{2}{*}{$\begin{array}{l}\text { Means of } \\
\text { seed } \\
\text { treatments }\end{array}$} \\
\hline & $\begin{array}{c}12 \\
\mathrm{~m} / \mathrm{mohs}\end{array}$ & $\begin{array}{c}10 \\
\mathrm{~m} / \mathrm{mohs}\end{array}$ & $\begin{array}{c}8 \\
\mathrm{~m} / \mathrm{mohs}\end{array}$ & $\begin{array}{c}6 \\
\mathrm{~m} / \mathrm{mohs}\end{array}$ & $\begin{array}{c}4 \\
\mathrm{~m} / \mathrm{mohs}\end{array}$ & \\
\hline Soaking in humic acid & 97.3 & 98.3 & 98.6 & 99.3 & 99.6 & 98.6 \\
\hline Priming in humic acid & 95.6 & 96.6 & 97.6 & 99.0 & 99.3 & 97.6 \\
\hline Soaking in water & 93.0 & 94.3 & 95.6 & 96.3 & 97.3 & 95.3 \\
\hline Priming in water & 92.3 & 93.6 & 94.6 & 95.6 & 97.6 & 94.8 \\
\hline Dressing with humicacid & 91.0 & 93.0 & 94.3 & 95.3 & 97.0 & 94.1 \\
\hline Dry seeds (control) & 85.0 & 89.6 & 92.3 & 94.3 & 96.3 & 91.5 \\
\hline Means of salinitylevels & 92.3 & 94.2 & 95.5 & 96.6 & 97.8 & \\
\hline \multicolumn{4}{|c|}{ LSD at $5 \%$ of seed treatments } & 0.8 & & \\
\hline \multicolumn{4}{|c|}{ LSD at $5 \%$ of salinity levels } & 0.7 & & \\
\hline \multicolumn{4}{|c|}{ LSD at $5 \%$ of seed treatments $\times$ salinity levels } & 1.8 & & \\
\hline
\end{tabular}

Significant differences in mean germination time (MGT) as affected by different salinity levels (Table 2). The increase in salinity level delayed germination from 1.194 day to 1.701 day at 4 and $12 \mathrm{dsm}^{-1}$, respectively. As salt concentration increased MGT increase. However, the shortest MGT (1.194 day), was obtained with control. The significant differences were noted in MGT of seed treatment methods. Soaking seed in humic acid produced the best value of MGT (1.141 day) followed by priming in humic acid method (1.365 day). However, the dressing method was the longest MGT of humic acid treatments (1.602 day). All treating seed methods with humic or distilled water under salinity levels decreased mean germination time as compared with dry seed (control) while, soaking or priming in distilled water were shorter mean germination time than dressing with humic. For example soaking in distilled water produced 1.600 and 1.700 day in salt concentration 10 and 12 $\mathrm{dsm}^{-1}$ while, it was 1.720 and 1.897 day with dressing method, respectively. This suggests that period treated $(12 \mathrm{~h})$ with humic was more viable than $0 \mathrm{~h}$ (dressing method). Priming in humic acid for $12 \mathrm{~h}$ duration may be increased dynamic reserve of seeds. This is similarly with Andoh and Kobata (2002) they reported that the effect of seed priming on germination indicated that germination increased in primed seeds due to some metabolic and biochemical changes during priming. For example, in the seeds part of the 
protein and carbohydrates are broken due to enzyme activity and the hydrolysis reaction. This process resulted in rapid germination and hence seedling emergence can be improved. Treating seed (either soaking or priming) with humic acid for $12 \mathrm{~h}$ caused decrease in MGT. The corresponding data was (1.200 and 1.563 day) in $10 \mathrm{ds} \mathrm{m}^{-1}$ and (1.233 and 1.673 day) in $12 \mathrm{ds} \mathrm{m}^{-1}$, while, it was (1.787 and 1.940 day) in dry seed, respectively. These results are similar in line with Jeannette et al. (2002). They found that the mean time to germination of almost all Phaseolus species increased with the addition of $\mathrm{NaCl}$ and this increase was greater in higher concentration as compared to low concentration.

Table 2: Mean germination time (MGT) as affected by seed treatments and salinity levels as well as their interaction under laboratory conditions.

\begin{tabular}{|c|c|c|c|c|c|c|}
\hline \multirow[b]{2}{*}{ Seed treatments } & \multicolumn{5}{|c|}{ Salinity levels } & \multirow{2}{*}{$\begin{array}{l}\text { Means of } \\
\text { seed } \\
\text { treatments }\end{array}$} \\
\hline & $\begin{array}{c}12 \\
\mathrm{~m} / \mathrm{mohs}\end{array}$ & $\begin{array}{c}10 \\
\mathrm{~m} / \mathrm{mohs}\end{array}$ & $\begin{array}{c}8 \\
\mathrm{~m} / \mathrm{mohs}\end{array}$ & \begin{tabular}{|c|}
6 \\
$\mathrm{~m} / \mathrm{mohs}$
\end{tabular} & \begin{tabular}{|c|}
4 \\
$\mathrm{~m} / \mathrm{mohs}$ \\
\end{tabular} & \\
\hline Soaking in humic acid & 1.233 & 1.200 & 1.157 & 1.103 & 1.013 & 1.141 \\
\hline Priming in humic acid & 1.637 & 1.563 & 1.303 & 1.217 & 1.103 & 1.365 \\
\hline Soaking in water & 1.700 & 1.600 & 1.437 & 1.297 & 1.167 & 1.440 \\
\hline Priming in water & 1.800 & 1.627 & 1.460 & 1.333 & 1.233 & 1.491 \\
\hline Dressing with humic acid & 1.897 & 1.720 & 1.600 & 1.480 & 1.313 & 1.602 \\
\hline Dry seeds (control) & 1.940 & 1.787 & 1.663 & 1.550 & 1.337 & 1.655 \\
\hline Means of salinity levels & 1.701 & 1.583 & 1.437 & 1.330 & 1.194 & \\
\hline \multicolumn{4}{|c|}{ LSD at $5 \%$ of seed treatments } & 0.014 & & \\
\hline \multicolumn{4}{|c|}{ LSD at $5 \%$ of salinity levels } & 0.013 & & \\
\hline \multicolumn{4}{|c|}{ LSD at $5 \%$ of seed treatments $\times$ salinity levels } & 0.032 & & \\
\hline
\end{tabular}

Regarding shoot length, the results obtained from Table 3 indicated that shoot lengths decreased as salinity levels increased, for the different salt concentrations. Shoot length at $4 \mathrm{dsm}^{-1}$ (control) was $10.38 \mathrm{~cm}$, and gradually decreased until reach to the shorter shoot length $(8 \mathrm{~cm})$ under $12 \mathrm{ds} \mathrm{m}^{-1}$ salt concentration, The reduction in root and shoot development may be due to toxic effects of the $\mathrm{NaCl}$ used as well as unbalanced nutrient uptake by the seedlings. It may be due to the ability of the root system to control entry of ions to the shoot is of crucial importance to plant survival in the presence of $\mathrm{NaCl}$ (Hajibagheri et al., 1989). When treated wheat seed with the studied different methods, shoot length varied from 8.04 to $10.38 \mathrm{~cm}$. While, the dry

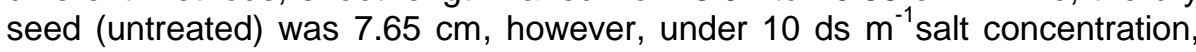
shoot length of untreated seed was the shorter one $(7.00 \mathrm{~cm})$ while, soaking seed with humic produced the tallest shoot length $(9.83 \mathrm{~cm})$. Humic acid has been reported to increase nutrient uptake and stimulate plant growth. It has been indicated that humic acid promoted plant growth by its effects on ion transfer at the root level, by activating the oxidation reduction state of the plant growth medium and so increased absorption of micronutrients by preventing precipitation in the nutrient solution (David et al., 1994). These results are in line with Malik and Azam (1985). 
Table 3: Shoot length $(\mathrm{cm})$ as affected by seed treatments and salinity levels as well as their interaction under laboratory conditions.

\begin{tabular}{|c|c|c|c|c|c|c|}
\hline \multirow[b]{2}{*}{ Seed treatments } & \multicolumn{5}{|c|}{ Salinity levels } & \multirow{2}{*}{$\begin{array}{c}\text { Means of } \\
\text { seed } \\
\text { treatments }\end{array}$} \\
\hline & \begin{tabular}{|c|}
12 \\
$\mathrm{~m} / \mathrm{mohs}$
\end{tabular} & $\begin{array}{c}10 \\
\mathrm{~m} / \mathrm{mohs}\end{array}$ & $\begin{array}{c}8 \\
\mathrm{~m} / \mathrm{mohs}\end{array}$ & $\begin{array}{c}6 \\
\mathrm{~m} / \mathrm{mohs}\end{array}$ & $\begin{array}{c}4 \\
\mathrm{~m} / \mathrm{mohs}\end{array}$ & \\
\hline Soaking in humic acid & 9.40 & 9.83 & 10.46 & 10.76 & 11.46 & 10.38 \\
\hline Priming in humic acid & 9.03 & 9.50 & 9.90 & 10.50 & 11.10 & 10.00 \\
\hline Soaking in water & 8.33 & 9.00 & 9.66 & 10.16 & 10.83 & 9.60 \\
\hline Priming in water & 8.00 & 8.76 & 9.16 & 9.80 & 10.56 & 9.26 \\
\hline Dressing with humic acid & 6.86 & 7.40 & 7.93 & 8.70 & 9.33 & 8.04 \\
\hline Dry seeds (control) & 6.36 & 7.00 & 7.50 & 8.40 & 9.00 & 7.65 \\
\hline Means of salinity levels & 8.00 & 8.58 & 9.10 & 9.72 & 10.38 & \\
\hline \multicolumn{4}{|c|}{ LSD at $5 \%$ of seed treatments } & 0.08 & & \\
\hline \multicolumn{4}{|c|}{ LSD at $5 \%$ of salinity levels } & 0.07 & & \\
\hline \multicolumn{4}{|c|}{ LSD at $5 \%$ of seed treatments $\times$ salinity levels } & 0.17 & & \\
\hline
\end{tabular}

As regard root length, salinity levels showed an adverse effect on root length (Table 4). The lower root length $(8.81 \mathrm{~cm})$, produced under $12 \mathrm{dsm}$ ${ }^{1}$ salt concentration. While, the tallest one $(14.24 \mathrm{~cm})$ was obtained under 4 $\mathrm{dsm}^{-1}$ salt concentration. Treated seed with humic acid or distilled water under the different salinity levels has had significant differences on root length. The best root length $(15.13 \mathrm{~cm})$ was obtained under $4 \mathrm{ds} \mathrm{m}^{-1}$ salt concentration while, the shortest one $(6.53 \mathrm{~cm})$ recorded with dry seed under $12 \mathrm{dsm}^{-1}$ salt concentration. This implies that the raise of salt concentration is a part from reducing root length. The root and shoot lengths are the most important parameters for salt stress because roots are in direct contact with soil and absorb water from soil and shoot supply it to the rest of the plant. For this reason, root and shoot length provides an important clue to the response of plants to salt stress (Jamil and Rha, 2004). Soaking in humic acid decreased the decline in root length under different salt concentrations as compared with the other seed treatment methods. However, the highest root length (10.66 $\mathrm{cm}$ ) obtained from soaking in humic method under12 $\mathrm{dsm}^{-1}$ salt concentration, while the dressing one was the inferior of seed treatment methods $(7.03 \mathrm{~cm})$. These results are supported by Vaughan (1974) who suggested that increased secondary root growth resulted from the formation of complexes of humic acid with iron in plant tissues preventing the cessation of root growth. 
Table 4: Root length $(\mathrm{cm})$ as affected by seed treatments and salinity levels as well as their interaction under laboratory conditions.

\begin{tabular}{|l|c|c|c|c|c|c|}
\hline \multirow{2}{*}{ Seed treatments } & \multicolumn{7}{|c|}{ Salinity levels } & $\begin{array}{c}\text { Means of } \\
\text { seed }\end{array}$ \\
\cline { 2 - 6 } & $\begin{array}{c}\mathbf{1 2} \\
\mathbf{m} / \mathbf{m o h s}\end{array}$ & $\begin{array}{c}\mathbf{1 0} \\
\mathbf{m} / \mathbf{m o h s}\end{array}$ & $\begin{array}{c}\mathbf{8} \\
\mathbf{m} / \mathbf{m o h s}\end{array}$ & $\begin{array}{c}\mathbf{6} \\
\mathbf{m} / \mathbf{m o h s}\end{array}$ & $\begin{array}{c}\mathbf{4} \\
\mathbf{m} / \mathbf{m o h s}\end{array}$ & treatments \\
\hline Soaking in humic acid & 10.66 & 11.43 & 13.03 & 14.70 & 15.13 & 12.99 \\
\hline Priming in humic acid & 10.06 & 11.10 & 12.76 & 14.13 & 14.83 & 12.58 \\
\hline Soaking in water & 9.50 & 10.53 & 12.40 & 13.50 & 14.40 & 12.06 \\
\hline Priming in water & 9.06 & 9.96 & 11.86 & 13.06 & 14.23 & 11.64 \\
\hline Dressing with humic acid & 7.03 & 8.53 & 10.96 & 12.40 & 13.60 & 10.50 \\
\hline Dry seeds (control) & 6.53 & 7.86 & 10.66 & 11.96 & 13.26 & 10.06 \\
\hline Means of salinity levels & 8.81 & 9.90 & 11.95 & 13.29 & 14.24 & \\
\hline LSD at 5\% of seed treatments & \multicolumn{7}{|l|}{0.09} & & \\
\hline LSD at 5\% of salinity levels & 0.08 & & \\
\hline LSD at 5\% of seed treatments $\times$ salinity levels & 0.21 & \\
\hline
\end{tabular}

The different salt concentrations had a significant effect on seedling dry weight (Table 5). Similar, trends observed with seedling dry weight. The maximum seedling dry weight $(354 \mathrm{mg})$ was obtained under $4 \mathrm{dsm}^{-1}$ while, the lowest one $(277 \mathrm{mg})$ was obtained under $12 \mathrm{dsm}^{-1}$ salt concentration. Soaking seed method in humic increased seedling dry weight than untreated seed while, soaking seed method in humic recorded the heaviest seedling dry weight $(315 \mathrm{mg})$ under12 $\mathrm{dsm}^{-1}$ salt concentration. Conversely, the dressing method was the inferior one $(261 \mathrm{mg})$ whereas, this value was directly above the value of untreated seed $(247 \mathrm{mg})$. Similar results were obtained by Ashraf et al. (2005) who reported that under saline conditions, depletion of $\mathrm{O}^{2}$ deprives the plants of its primary energy source and accumulation of internal ethylene causes the inhibition of root elongation by reducing root growth, which consequently reduces root fresh and dry biomass. It was reported that high salt concentration in the nutrient medium causes stunted growth in plants (Ashraf et al., 1999; Cherian et al., 1999 and Takemura et al., 2000). The immediate response of salt stress is reduction in rate of leaf surface expansion (Wang and Nil, 2000), these results in a considerable decrease in the fresh and dry weights of shoot, leaves and roots (Ali Denar et al., 1999; Chartzoulakis and Klapaki, 2000 and Ashraf et al., 2005). 
Table 5: Seedlings dry weight $(\mathrm{mg})$ as affected by seed treatments and salinity levels as well as their interaction under laboratory conditions.

\begin{tabular}{|l|c|c|c|c|c|c|}
\hline \multirow{2}{*}{ Seed treatments } & \multicolumn{7}{|c|}{ Salinity levels } & Means of \\
\cline { 2 - 6 } & $\begin{array}{c}\mathbf{1 2} \\
\mathbf{m} / \mathbf{m o h s}\end{array}$ & $\begin{array}{c}\mathbf{1 0} \\
\mathbf{m} / \mathbf{m o h s}\end{array}$ & $\begin{array}{c}\mathbf{8} \\
\mathbf{m} / \mathbf{m o h s}\end{array}$ & $\begin{array}{c}\mathbf{6} \\
\mathbf{m} / \mathbf{m o h s}\end{array}$ & $\begin{array}{c}\mathbf{4} \\
\mathbf{m} / \mathbf{m o h s}\end{array}$ & $\begin{array}{c}\text { seed } \\
\text { treatments }\end{array}$ \\
\hline Soaking in humic acid & 315 & 335 & 352 & 371 & 385 & 351 \\
\hline Priming in humic acid & 298 & 315 & 332 & 352 & 372 & 334 \\
\hline Soaking in water & 274 & 267 & 319 & 341 & 360 & 312 \\
\hline Priming in water & 267 & 287 & 311 & 333 & 355 & 310 \\
\hline Dressing with humic acid & 261 & 276 & 302 & 323 & 345 & 301 \\
\hline Dry seeds (control) & 247 & 250 & 268 & 293 & 311 & 274 \\
\hline Means of salinity levels & 277 & 288 & 314 & 335 & 354 & \\
\hline LSD at 5\% of seed treatments & 8.1 & & \\
\hline LSD at 5\% of salinity levels & 7.4 & & \\
\hline LSD at 5\% of seed treatments $\times$ salinity levels & 18.1 & & \\
\hline
\end{tabular}

\section{II- Pot experiment}

There was a significant difference between seed treatment methods under salt concentrations on emergence percentage (Table 6). Soaking and priming in humic acid methods produced the highest emergence percentages under $12 \mathrm{ds} \mathrm{m}^{-1}$ (94.3 and 92.3\%) while, untreated seed produced the lowest value, which was $78.3 \%$. The increment in emergence percentage under 12 ds $\mathrm{m}^{-1}$ after soaking seed in humic was $20 \%$ which more than priming and dressing methods (18 and 5\%, respectively). These findings are in conformity with Killi (2004), Patil (2011) and Szczepanek and Wilczewski (2011) they demonstrated that the effect of soaking in potassium humate solution caused significant increases in germination characteristics. Whereas, David et al. (1994) found that the immersion of seeds in a sodium humate solution was reported to increase water absorption, respiration and germination percentage.

The differences between salinity levels were also noted in mean emergence time (Table 6). The increase in salinity levels were faced by MET values, whereas the delayed emergence (7.187 days) noted under $12 \mathrm{dsm}$ ${ }^{1}$ salt concentration. Soaking or priming wheat seed in humic acid emerged seedling more rapidly than untreated one which reflected by its shortest MET ( 7.051 and 7.090 days, respectively). Meanwhile, the dry seed treatment (control) was the longest MET (7.222 days). Since the prolonged emergence has often associated with increase in salt concentration so, the best use of humic acid seed treatment was soaking method. Accordingly, soaking wheat seed in humic acid resulted in the faster emergence (7.087 days) under the higher salt concentration $\left(12 \mathrm{dsm}^{-1}\right)$ while, the dressing method was just above control (7.220 days). These results are in line with Mirzaei et al. (2012); Muhammad and Hussain (2012) and Hussain et al. (2013) they reported that seed germination and seedling growth are the most sensitive stages to salinity stress. 
Table 6: Emergence \% and mean emergence time (MET) as affected by seed treatments and salinity levels as well as their interaction under pots conditions.

\begin{tabular}{|c|c|c|c|c|c|c|c|c|}
\hline \multirow{3}{*}{$\begin{array}{l}\text { Seed } \\
\text { treatments }\end{array}$} & \multicolumn{4}{|c|}{ Emergence \% } & \multicolumn{4}{|c|}{ MET } \\
\hline & \multicolumn{3}{|c|}{ Salinity levels } & \multirow{2}{*}{$\begin{array}{c}\text { Means } \\
\text { of seed } \\
\text { treat- } \\
\text { ments }\end{array}$} & \multicolumn{3}{|c|}{ Salinity levels } & \multirow{2}{*}{\begin{tabular}{|c|}
$\begin{array}{c}\text { Means of } \\
\text { seed }\end{array}$ \\
$\begin{array}{c}\text { Treat- } \\
\text { ments }\end{array}$
\end{tabular}} \\
\hline & $\begin{array}{c}12 \\
\mathrm{~m} / \mathrm{mohs}\end{array}$ & $\begin{array}{c}8 \\
\mathrm{~m} / \mathrm{mohs}\end{array}$ & $\begin{array}{c}4 \\
\mathrm{~m} / \mathrm{mohs}\end{array}$ & & $\begin{array}{c}12 \\
\mathrm{~m} / \mathrm{mohs}\end{array}$ & $\begin{array}{c}8 \\
\mathrm{~m} / \mathrm{mohs}\end{array}$ & $\begin{array}{c}4 \\
\mathrm{~m} / \mathrm{mohs}\end{array}$ & \\
\hline Soaking in humic acid & 94.3 & 96.3 & 99.3 & 96.6 & 7.087 & 7.047 & 7.020 & 7.051 \\
\hline Priming in humic acid & 92.3 & 94.3 & 99.0 & 95.2 & 7.150 & 7.073 & 7.047 & 7.090 \\
\hline Soaking in water & 89.3 & 93.6 & 97.3 & 93.4 & 7.170 & 7.110 & 7.067 & 7.116 \\
\hline Priming in water & 87.0 & 92.3 & 97.3 & 92.2 & 7.187 & 7.117 & 7.077 & 7.127 \\
\hline Dressing with humic acid & 82.3 & 88.3 & 96.3 & 89.0 & 7.220 & 7.157 & 7.100 & 7.159 \\
\hline Dry seeds (control) & 78.3 & 85.3 & 94.6 & 86.1 & 7.310 & 7.227 & 7.130 & 7.222 \\
\hline Means of salinity levels & 87.2 & 91.7 & 97.3 & & 7.187 & 7.122 & 7.073 & \\
\hline \multicolumn{3}{|c|}{ LSD at $5 \%$ of seed treatments } & 0.5 & & \multicolumn{3}{|c|}{0.005} & \\
\hline \multicolumn{3}{|c|}{ LSD at $5 \%$ of salinity levels } & 0.4 & & \multicolumn{3}{|c|}{0.004} & \\
\hline \multicolumn{3}{|c|}{$\begin{array}{l}\text { LSD at } 5 \% \text { of seed treatments } \times \\
\text { salinity levels }\end{array}$} & 0.9 & & \multicolumn{3}{|c|}{0.009} & \\
\hline
\end{tabular}

Difference in treatment main effects are shown Table 7 . The salinity levels of pot soil have had significant differences on shoot length. The best value was obtained under $4 \mathrm{dsm}^{-1}(27.83 \mathrm{~cm})$ while, the lowest $(19.81 \mathrm{~cm})$ was under $12 \mathrm{dsm}^{-1}$ salt concentration. Similarly, shoot development showed significant differences among seed treatment methods. The tallest shoot length was obtained from soaking seed in humic acid $(28.11 \mathrm{~cm})$ while, the shortest one $(19.11 \mathrm{~cm})$ was obtained with untreated seed followed by dressing method $(21.44 \mathrm{~cm})$.

Foliar application influenced shoot length (Table 7). Foliar application with humic acid produced the maximum shoot length $(26.53 \mathrm{~cm})$, followed by sprayed with water and then without foliar application $(23.07$ and $22.09 \mathrm{~cm})$.

A perusal of transformed data regarding shoot length (Table 8) depicted that interaction among seed treatment methods, salinity levels and foliar application was significant. However, the efficiency of humic acid as a combination of seed soaking and foliar application is reflected by its tallest shoot length $(35 \mathrm{~cm})$ under $4 \mathrm{dsm}^{-1}$ salt concentrations and was $31 \mathrm{~cm}$ without foliar spray. Similarly, shoot length under $12 \mathrm{dsm}^{-1}$ salt concentrations $(26.33 \mathrm{~cm})$ produced from used humic acid as a combination of seed soaking and foliar application. While, shoot length was $22.66 \mathrm{~cm}$ when soaked wheat seed in humic acid only. By other way, untreated seed planted at $12 \mathrm{dsm}^{-1}$ produced $14.33 \mathrm{~cm}$ shoot length, when priming in humic acid was $20.33 \mathrm{~cm}$ but, it reach to $24.66 \mathrm{~cm}$ when sprayed their seedlings by humic acid. Nevertheless, foliar spray with humic acid increased shoot length obtained from dressing method from 16.33 to $20.66 \mathrm{~cm}$ under $12 \mathrm{dsm}^{-1}$ salt concentration. These indicate that, the application of humic acid as soaking or foliar spray separately was effective and more effective especially when humic acid foliar application preceded by soaking or priming method. 
As regard root length, statistical analysis of data showed a significant difference between salinity levels on root length (Table 7). Planting wheat seed in $12 \mathrm{ds} \mathrm{m}^{-1}$ salt concentration induced significant reduction in root length was $35 \%$ than in in $4 \mathrm{dsm}^{-1}$ salt concentration. This may be to the direct contact with soil. Treated seed with different methods resulted in increment in root length (Table 7). As shoot length, the efficiency of humic acid as a combination of seed soaking and foliar application is reflected on root length under high salinity level (Table 8). Accordingly, sprayed seedlings resulted from dry seed with humic acid was evenly in shoot length with those from priming seed in distilled water under $12 \mathrm{dsm}^{-1}(17.33$ and $17.00 \mathrm{~cm})$. But when sprayed those seedlings resulted in $21.33 \mathrm{~cm}$ shoot length. Untreated seed planted at $12 \mathrm{dsm}^{-1}$ produced $5.36 \mathrm{~cm}$ root length, when soaking in humic acid was $6.96 \mathrm{~cm}$ but, it reach to $8.13 \mathrm{~cm}$ when sprayed their seedlings by humic acid. The root and shoot lengths are the most important parameters for salt stress because roots are in direct contact with soil and absorb water from soil and shoot supply it to the rest of the plant. For this reason, root and shoot length provides an important clue to the response of plants to salt stress (Jamil and Rha, 2004). These results are supported by Jackson (1993) who stated that foliar use of humic acid derivatives is reported to be very effective because the humic molecules can get into the cellular nutrient stream and make the cellular membrane more permeable allowing the improvement of nutrient flow and cell division. As the case with the shoot and root lengths, higher salinity level also showed a low seedling dry weight values, while the lower salinity level showed heaviest seedling dry weight (Table 7). Consequently, soaking seed in humic acid method presented the best seedling dry weight $(1039 \mathrm{mg})$ while, the dressing method was the inferior one $(961 \mathrm{mg})$. 
Table 7: Shoot and root lengths and seedlings dry weight as affected by seed treatments, salinity levels and foliar application treatments as well as their interactions under pots conditions.

\begin{tabular}{|c|c|c|c|}
\hline Treatments & $\begin{array}{l}\text { Shoot length } \\
(\mathrm{cm})\end{array}$ & $\begin{array}{l}\text { Root length } \\
(\mathrm{cm})\end{array}$ & $\begin{array}{l}\text { Seedlings dry weight } \\
\text { (mg) }\end{array}$ \\
\hline \multicolumn{4}{|c|}{ A- Seed treatments: } \\
\hline Soaking in humic acid & 28.11 & 9.34 & 1039 \\
\hline Priming in humic acid & 27.00 & 8.83 & 1024 \\
\hline Soaking in water & 24.40 & 8.17 & 987 \\
\hline Priming in water & 23.33 & 7.80 & 979 \\
\hline Dressing with humic acid & 21.44 & 7.55 & 961 \\
\hline Dry seeds (control) & 19.11 & 7.30 & 940 \\
\hline LSD at $5 \%$ & 0.36 & 0.08 & 2.2 \\
\hline \multicolumn{4}{|c|}{ B- Salinity levels: } \\
\hline $12 \mathrm{~m} / \mathrm{mohs}$ & 19.81 & 6.50 & 932 \\
\hline $8 \mathrm{~m} / \mathrm{mohs}$ & 24.05 & 8.00 & 984 \\
\hline $4 \mathrm{~m} / \mathrm{mohs}$ & 27.83 & 9.98 & 1049 \\
\hline LSD at $5 \%$ & 0.25 & 0.05 & 1.2 \\
\hline \multicolumn{4}{|c|}{ C- Foliar application treatments: } \\
\hline Without & 22.09 & 7.73 & 964 \\
\hline Water & 23.07 & 8.05 & 983 \\
\hline Humic acid & 26.53 & 8.71 & 1017 \\
\hline LSD at $5 \%$ & 0.25 & 0.06 & 1.6 \\
\hline \multicolumn{4}{|c|}{ D- Interactions: } \\
\hline$A \times B$ & * & * & * \\
\hline$A \times C$ & * & * & * \\
\hline $\mathrm{B} \times \mathrm{C}$ & * & * & * \\
\hline$A \times B \times C$ & * & * & * \\
\hline
\end{tabular}

Significant differences in physiological seed quality (indicated by seedling dry weight) as affected by different seed treatment methods under salinity levels and foliar application (Table 8). Foliar application with humic acid consistently remains higher seedling dry weight as compared without foliar treatment. These increase trends occurred even through seed treatment methods and increase in salinity levels with gradually decrease in seedling dry weight. Accordingly, seedling dry weight increased through seed treatment methods from $998 \mathrm{mg}$ (dry seed) to $1041 \mathrm{mg}$ (soaking in humic) under normal soil $\left(4 \mathrm{dsm}^{-1}\right)$ and without humic acid foliar application. While, foliar application with humic acid raised the values, to 1039 and $1136 \mathrm{mg}$, respectively. Likewise, seedling dry weight increased from 854 to $970 \mathrm{mg}$ resulted from soaking dry seed in humic acid under12 dsm ${ }^{-1}$ salt concentration. But, the increase was from 888 to $1040 \mathrm{mg}$ when sprayed seedling with humic acid. Adverse soil conditions render many essential nutrients unavailable for root absorption. The root absorption and translocation become slower which increase the need to exploit the capacity of plant leaves to absorb nutrients. Ali and Elbordiny (2009) reported that foliar sprays can improve the growth of plant and combination of soaking seeds with potassium humate and foliar application were more effective on $\mathrm{N}$, $\mathrm{P}$ and $\mathrm{K}$ uptake by wheat plant as compared to soaking seeds alone. Our 
findings are in agreement with Waqas et al. (2014) they reported that humic acid application in all the three methods (soil applied, seed priming and foliar spray) significantly enhances plant growth of mungbean. While, Alam (2006) found that foliar supply of nutrients can result in increasing the photosynthetic efficiency and it is possible to modify the physiology of leaf.

Table 8: Shoot and root lengths and seedlings dry weight as affected by the interaction among seed treatments, salinity levels and foliar application treatments under pots conditions.

\begin{tabular}{|c|c|c|c|c|c|c|c|c|c|c|}
\hline \multicolumn{2}{|c|}{ Characters } & \multicolumn{3}{|c|}{ Shoot length $(\mathrm{cm})$} & \multicolumn{3}{|c|}{ Root length (cm) } & \multicolumn{3}{|c|}{$\begin{array}{c}\text { Seedlings dry } \\
\text { weight (mg) }\end{array}$} \\
\hline \multirow[b]{2}{*}{\begin{tabular}{|l|} 
Seed \\
treatments
\end{tabular}} & \multirow[b]{2}{*}{$\begin{array}{l}\text { Salinity } \\
\text { levels }\end{array}$} & \multicolumn{9}{|c|}{ Foliar application treatments } \\
\hline & & \begin{tabular}{|c|} 
With- \\
out
\end{tabular} & & Humi & $\begin{array}{l}\text { With- } \\
\text { out }\end{array}$ & & $\begin{array}{l}\text { Humi } \\
\text { c acid }\end{array}$ & $\begin{array}{c}\text { With- } \\
\text { out }\end{array}$ & & $\begin{array}{l}\text { Humi } \\
\text { c acid }\end{array}$ \\
\hline \multirow{3}{*}{$\begin{array}{l}\text { Soaking in } \\
\text { humic acid }\end{array}$} & $12 \mathrm{~m} / \mathrm{m}$ & 22.66 & 23.33 & 26.33 & 6.96 & 7.20 & 8.13 & 970 & 990 & 1040 \\
\hline & & 25.66 & 26.00 & 31.33 & 8.83 & 9.13 & 9.6 & 998 & 29 & 1063 \\
\hline & & & & 35.00 & 10. & 11.2 & & 1041 & & \\
\hline \multirow{3}{*}{$\begin{array}{l}\text { Priming in } \\
\text { humic acid }\end{array}$} & $12 r$ & & & 24.66 & & 80 & & 954 & & 1012 \\
\hline & & & & & 8.2 & & & 985 & & 56 \\
\hline & & & & 34.33 & 10.13 & 10.56 & 11.36 & 1034 & & 1110 \\
\hline \multirow{3}{*}{$\begin{array}{l}\text { Soaking in } \\
\text { water }\end{array}$} & $12 \mathrm{~m}$ & & & 22.00 & & 6.43 & 7.00 & 908 & 924 & 948 \\
\hline & & & & 28.66 & 7. & & 8.70 & 962 & 980 & 1013 \\
\hline & & & \begin{tabular}{|l}
27 \\
27
\end{tabular} & 66 & & & 10.16 & \begin{tabular}{|l|}
1024 \\
\end{tabular} & 1042 & 1086 \\
\hline \multirow{3}{*}{$\begin{array}{l}\text { Priming in } \\
\text { water }\end{array}$} & & & & 21.33 & & & & 903 & 917 & 939 \\
\hline & & 22. & 22.66 & 27.66 & 7.20 & 7.60 & 10 & 956 & 965 & 1001 \\
\hline & & 25.5 & 26.00 & 29.33 & 9.03 & 9.40 & 10.10 & \begin{tabular}{|l|}
1018 \\
\end{tabular} & 1038 & 1079 \\
\hline \multirow{3}{*}{$\begin{array}{l}\text { Dressing } \\
\text { with humic } \\
\text { acid }\end{array}$} & 12 & 16.3 & 17.00 & 20.66 & 5.60 & 5.80 & 6.80 & 884 & 891 & 913 \\
\hline & & & & 24.00 & & 7.13 & & 944 & 954 & 983 \\
\hline & & 23.6 & 24.33 & 27.33 & 8.83 & 9.20 & 90 & 1007 & 1020 & 1056 \\
\hline \multirow{3}{*}{$\begin{array}{l}\text { Dry seeds } \\
\text { (control) }\end{array}$} & $12 \mathrm{~m} / \mathrm{mohs}$ & 14.33 & \begin{tabular}{|l|}
15.33 \\
\end{tabular} & 17.33 & 5.36 & 5.70 & 6.20 & 854 & 862 & 888 \\
\hline & $8 \mathrm{~m} /$ & 17.33 & 18.00 & 20.66 & 6.63 & 6.93 & 7.40 & 924 & 932 & 955 \\
\hline & & & 22.66 & 25.33 & 8.90 & 9.00 & 9.60 & 998 & 1012 & 1039 \\
\hline \multicolumn{2}{|l|}{ LSD at $5 \%$} & \multicolumn{3}{|c|}{1.07} & & \multicolumn{3}{|c|}{6.8} \\
\hline
\end{tabular}

\section{CONCLUSIONS}

It has been concluded from this study that humic acid could be successfully used for soaking, priming or dressing purpose of wheat seed to speed up the germination process and get higher germination of seeds. The maximum root elongation and percent seed germination was recorded with soaking, followed by priming in humic acid. Combination of soaking seeds and foliar application of seedlings with humic acid were more effective on seedling vigor as compared to soaking or priming seeds alone, the presowing seed treatment which is an easy and low risk technique may be used as an alternative approach to alleviate agricultural salinity problems. 


\section{REFERENCES}

Afzal, I.; S. M.A. Basra; M. Farooq and A. Nawaz (2006). Alleviation of salinity stress in spring wheat by hormonal priming with $A B A$, salicylic acid and ascorbic acid. Int. J. Agri. Biol., 8 (1):23-28.

Agrawal, P.K. (1986). Seed Vigor Concepts and Measurements. In: Seed Production Technology, Srivastava, J.P. and L.T. Simarsk (Ed.). ICARDA, Aleppo, Syria, pp: 190-198.

Akbarimoghaddam, H.; H.M. Galavi; A. Ghanbari and N. Panjehkeh (2011). Salinity effects on seed germination and seedling growth of bread wheat cultivars. Trakia J. Sci., 9(1):43-50.

Alam, S.M. ( 2006). Foliar spray for plant growth. Dawn internet edition Zilhaj, 03: 1427.

Ali Denar, H.M.; G. Ebert and P. Ludders (1999). Growth, chlorophyll content, photosynthesis and water relation in guava (Psidium guaava L.) under salinity and different nitrogen supply. Garten-Bauwissenschaft, 64: 5459.

Ali Laila, K.M. and M.M. Elbordiny (2009). Response of wheat plants to potassium humate application J. Appl. Sci. Res., 5(9): 1202-1209.

Andoh, $\mathrm{H}$. and T. Kobata ( 2002). Effect of seed hardening on the seedling emergence and alpha-amylase activity in the grains of wheat and rice sown in dry soil. Japan J. Crop Sci., 71: 220-225.

Asenjo, M.C.; J.L. Gonzales and J.M. Maldonado (2000). Influnce of humic extracts on germination and growth of ryegrass. Commun. Soil Sci. Plant Anal., 31: 101-114

Asgharipour, M. R. and M. Rafiei (2011). The effect of different concentrations of humic acid on seed germination behavior and vigor of barley. Aust. J. Basic \& Appl. Sci., 5(12): 610-613.

Ashraf, M.Y.; K. Akhtar; G. Sarwar and M. Ashraf (2005). Role of rooting system in salt tolerance potential of different guar accessions. Agron. Sust. Dev., 25: 243-249.

Ashraf, M.Y.; R.A. Wahed; A.S. Bhatti; G. Sarwar and Z. Aslam (1999). Salt tolerant potential in different Brassica species. Growth studies. In: Halophytes Uses in Different Climates-II. (Eds.): H. Hamdy, H. Lieth, M. Todorovic and M. Moschenko. Backhuys Publishers, Leiden, The Netherlaands. pp. 119-125.

Ayuso, M.; T. Hernandez; C. Garcia and J. Pascual (1996). Stimulation of barley growth and nutrient absorption by humic substances originating from various organic materials. Biores. Technol., 57, 251-257.

Canellas, L.; F. Olivares; A. Okorokova-Facanha and A. Facanha ( 2002). Humic acids isolated from earthworm compost enhance root elongation, lateral root emergence, and plasma membrane $\mathrm{H}_{+}-\mathrm{ATPase}$ activity in maize roots. Plant Physiol. 130, 1951-1957.

Chartzoulakis, K. and G. Klapaki ( 2000). Response of two greenhouse pepper hybrids to $\mathrm{NaCl}$ salinity during different growth stages. Sci. Hortic., 86: 247-260. 
Cherian, S.; M.P. Reddy and J.B. Pandya (1999). Studies on salt tolerance in Avicennia marina (Forstk.) Vierh: effect of $\mathrm{NaCl}$ salinity on growth, ion accumulation and enzyme activity. Indian J. Plant Physiol., 4: 266-270.

Cooper, R.; L. Chunhua and D. Fisher (1998). Influence of humic substances on rooting and nutrient content of creeping bentgrass. Crop Sci., 38, 1639-1644.

Darra, B.L.; S.P. Seth; H. Singh and R.S. Mendiratta (1973). Effect of hormone-directed presoaking on emergence and growth of osmotically stressed wheat (Triticum aestivum L.). Agron. J., 65: 292-295.

Datta, K.S.; S.K. Varma; R. Angrish; B. Kumar and P. Kumari (1998). Alleviation of salt stress by plant growth regulators in (Triticum aestivum L.). Biol. PI., 40: 269-275.

David, P.P.; P.V. Nelson and D.C. Sanders (1994). A humic acid improves growth of tomato seedling in solution culture. J. PI. Nutr., 17: 173-84.

Dursun, A.; I. Guvenc and M. Turan (1999). Macro and micro nutrient contents of tomato and eggplant seedlings and their effects on seedling growth in relation to humic acid application. Improved Crop Quality by Nutrient Management. Kluwer Acedemic Publishers Ordrecht. Boston. London.

Ellis, R. H. and E. H. Roberts (1981). The quantification of ageing and survival in orthodox seeds. Seed Sci. and Tech., 9: 377-409.

Eskandari, H. and K. Kazemi (2011). Germination and seedling properties of different wheat cultivars under salinity conditions. Not. Sci. Biol., $3(3): 130-134$

Garg, B.K. and I.C. Gupta (1997). Plant Relations to salinity. In: Saline wastelands environment and plant growth. PP: 79-121. Scientific Publishers, Jodhpur.

Gomez, K.A. and A.A. Gomez (1984). Statistical Procedures for Agricultural Research. $2^{\text {nd }} E d n$., Jhon Wiley and Sons Inc., New York, pp: 95-109.

Habashy, N.R. and Laila M. Aly (2005). Effects of organic growth - promoting substances as humic acids and indool- acetic acid on wheat crop with special reference to some chemical composition. Minufiya J. Agric. Res., 30: 1607-1624.

Hajibagheri, M.A.; A.R. Yeo; T.J. Flowers and J.C. Collins (1989). Salinity resistance in Zea mays fluxes of potassium, sodium and chloride, cytoplasmic concentrations and microsomal membrane lipids. Plant, Cell and Envir., 12: 753-757.

He, Y.L.; Y.L. Liu; Q. Chen and A.H. Bian (2002). Thermotorerance related to antioxidation induced by salicylic acid and heat hardening in tall fescue seedlings. J. Plant Physiol. Mol. Biology, 28(2): 89-95.

Hussain,S.; A. Khaliq; A. Matloob; M. A. Wahid and I. Afzal (2013). Germination and growth response of three wheat cultivars to $\mathrm{NaCl}$ salinity. Soil Environ. 32(1): 36-43.

ISTA (1985). International rules for seed testing. Seed Sci. and Tech., 13, 299-320.

Jackson, W.R. (1993). Organic Soil Conditioning, "Humic, Fulvic and Microbial Balance ". Jackson Research Center. 946p. 
Jamil, M. and E.S. Rha (2004). The effect of salinity ( $\mathrm{NaCl})$ on the germination and seedling of sugar beet (Beta vulgaris L.) and cabbage (Brassica oleracea capitata L.), Korean J. plant Res. 7: 226-232.

Jeannette, S.; R. Craig and J.P. Lynch (2002). Salinity tolerance of phaseolus species during germination and early seedling growth, Crop Sci., 42: 1584-1594

Kawaguchi, K. (1974). "Soil Water and Soil Air," In: K. Kawaguchi, K. Kumada, S. Aomine, S. Kosaka, H. Okajima, S. Sasaki, Y. Takai, I. Yamane and S. Hunahiki, Eds., Soil Science, Asakurasyotenn Press, Tokyo, pp. 82-97.

Khan, A.R. and S. Mir (2002). Plant growth stimulation of lignite humic acid part II. Effect of lignite derived ammonium humate on wheat (Triticum aestivum L.) crop using different levels of phosphate fertilizer. Pakistan J. Sci. Indust. Res., 45: 273-276.

Killi, F., (2004). Effects of potassium humate solution and soaking on germination characteristics of undelinted cotton seeds (Gossypium hirsutum L.). J of Environ. Biol., 25: 395-398.

Lulakis, M.D. and S.I. Petsas (1995). Effects of humic substances from vinecanes mature compost on tomato seedling growth. Bioresource Technol., 54: 179-182.

Maas, E.V. and R.H. Nieman (2000). Physiology of plant tolerance to salinity. In: Crop Tolerance and suboptimal land conditions, 1978, Chap.13, 277-299

Malik, K.A. and F. Azam (1985). Effects of humic acids on wheat seedling growth. Enviro. and Exp. Bot., 25: 245-252.

Matsushima, K. andJ. Sakagami (2013). Effects of seed hydropriming on germination and seedling vigor during emergence of rice under different soil moisture conditions. American J. of Plant Sci., 4 (8): 15841593.

Mirzaei, I.; R. Naseri; T. Emami and A. Jozeyan (2012). Effect of salinity on germination and seedling growth of bread wheat(Triticum aestivum L.) Int. J. Agric. Crop Sci. , 4 (15): 1089-1091.

Muhammad, Z. and F. Hussain (2010). Effect of $\mathrm{NaCl}$ salinity on the germination and seedling growth of some medicinal plants. Pakistan $\mathrm{J}$. Bot., 42(2): 889-897.

Muhammad, Z. and F. Hussain (2012). Effect of $\mathrm{NaCl}$ salinity on the germination and seedling growth of seven wheat genotypes. Pak. J. Bot., 44(6):1845-1850.

Nardi, S.; D. Pizzeghello; A. Muscolo and A. Vianello (2002). Physiological Effects of Humic Substances on Higher Plants. Soil Biol. and Bioch., 34:1527-1536.

Patil, R.(2011). Effect of potassium humate and deproteinised Juice (DPJ) on seed germination and seedling growth of wheat and jowar. Ann. of Biol. Res., 2 (2):26-29.

Piper, C. S. (1950). "Diagnosis and properties of saline and alkali soils" USA. Handbook No. 60.

Rhoades, J. D.; A. Kandiah and A. M. Mashali (1992). The Use of saline waters for Crop production. FAO Irr. and Drain. Rome. 
Sakr, M. T. and M.A. EL-Metwally (2009). Alleviation of the harmful effects of soil salt stress on growth, wield and endogenous antioxidant content of wheat plant by application of antioxidants. Pakistan J. of Biol. Sci., 12 (8): 624-630.

Singh, H. and B.L. Dara (1971). Influence of presoaking of seeds with gibberellin and auxins on growth and yield attributes of wheat (Triticum aestivum L.) under high salinity, sodium adsorption ratio and boron levels. Indian J. Agric. Sci., 41: 998-1003.

Smith, P.T. and B.G. Comb (1991). Physiological and enzymatic activity of pepper seeds (Capsicum annuum) during priming. Physiol. Plant, 82:71-78.

Snedecor, G. W. and W. G. Cochran (1980). Statistical methods. $7^{\text {th }}$ edition, lowa State University Press, Ames, lowa.

Szczepanek, M. and E. Wilczewski (2011). Effect of humic substances on germination of wheat and barley under laboratory conditions. Acta Sci. Pol., Agric., 10(1): 79-86.

Takemura, T.; N. Hanagata; Z. Dubinsky and I. Karube (2000). Molecular characterization and response to salt stress of mRNAs encoding cytosolic $\mathrm{CU} / \mathrm{Zn}$ superoxide dismutase and catalase from Bruguiera gymnorrhiza. Trees- Struct. Funct., 16: 94-99.

Tejada, M. and J.L. Gonzalez (2003). Effects of foliar application of a byproduct of the two- step olive oil mill process on maize yield. Agronomie, 23: 617-623.

Turkmen, O.; D. Semra; S. Suat and D. Altilla (2005). Effects of Arbuscular Mycorrhizal Fungus and Humic Acid on the Seedling Development and Nutrient Content of Pepper Grown under Saline Soil Conditions J. Biol. Sci., (5):568-574.

Vaughan, D. (1974). A possible mechanism for humic acid action on cell elongation in root segments of Pisum sativum under aseptic conditions. Soil Biol. Biochem., 6:241-247.

Wang, Y. and N. Nil (2000). Changes in chlorophyll, ribulose bisphosphate carboxylase-oxygenase, glycinebetain content, photosynthesis and transpiration in Amaranthus tricolor leaves during salt stress. J. Hortic. Sci. Biotech., 75: 623-627.

Waqas, M.; B. Ahmad; M. Arif; F. Munsif; A.L. Khan; M Amin; S. M. Kang; Y. H. Kim and I. J. Lee (2014). Evaluation of Humic Acid Application Methods for Yield and Yield Components of Mungbean. American J. of Plant Sci., 5: 2269-2276. 
إستجابة إنبـات وقوة بـادرات القمـح لطرق معاملة التقـاوى تحت ظروف الإجهاد

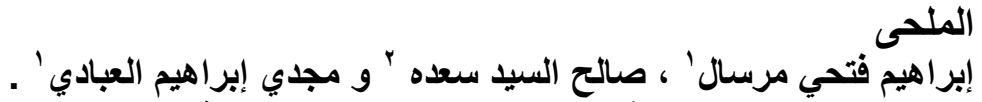

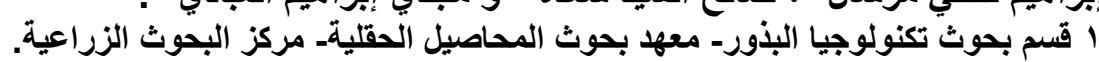

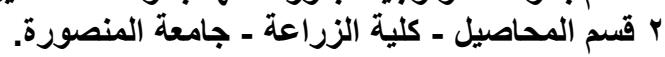

تعتبر زيادة قدرة المحاصيل الحقلية لتحمل الإجهاد الناتج عن الظروف البيئية من العوامل

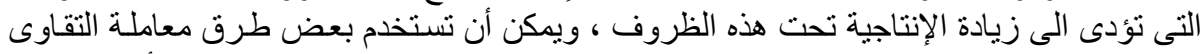

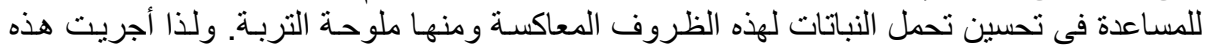

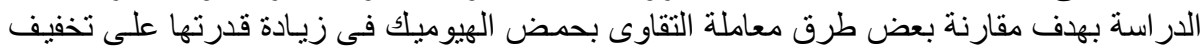

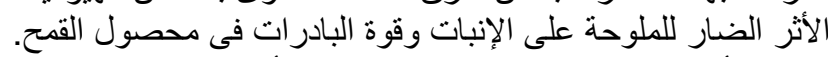

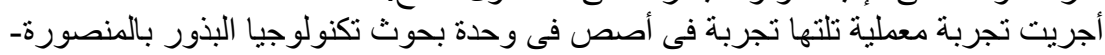

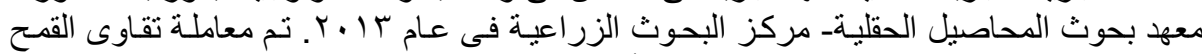

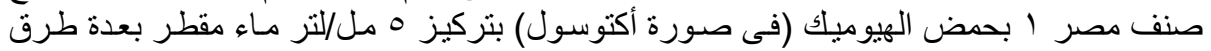

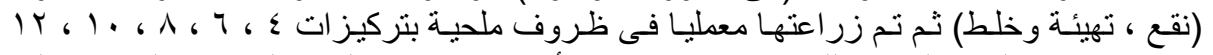

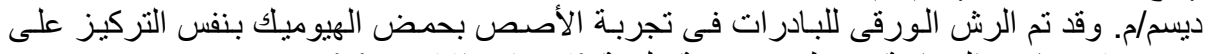

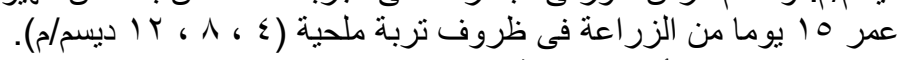

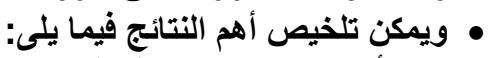

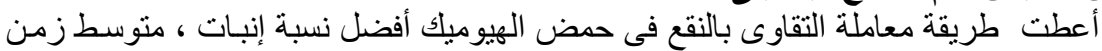

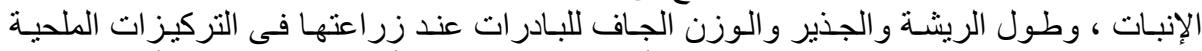

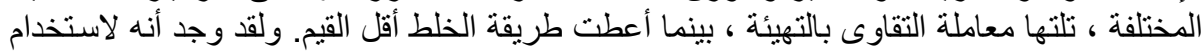

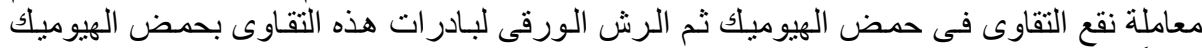

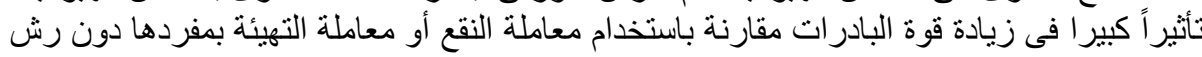

توصى هذه الدراسة باستخدام بعض طرق معاملة التقاوى قبل الزر اعة لكونها طرق سهلة ورقى.

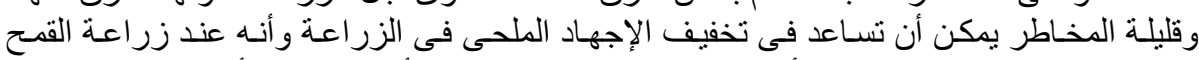

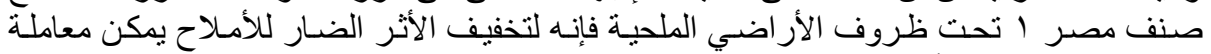

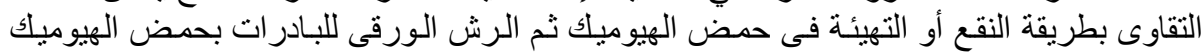
حيث يؤدى ذللك الى زيادة نسبة الإنبات و قوة البادرات. 